KeMAS 16 (2) (2020) 225-232
Jirnal Kesehatan Masyarakat

\title{
The Implementation of Community Based on Total Sanitation among Fisherman Families in West Java
}

\author{
Clara R.P. Ajisuksmo ${ }^{1 \bowtie}$, Nilla S.D. Iustitiani² \\ ${ }^{1}$ Faculty of Psychology, Atma Jaya Catholic University of Indonesia \\ ${ }^{2}$ Centre for Societal Development Studies, Atma Jaya Catholic University of Indonesia
}

\begin{tabular}{l} 
Article Info \\
\hline Article History: \\
Submitted January 2020 \\
Accepted May 2020 \\
Published November 2020 \\
\hline Keywords: \\
Community led total \\
sanitation, open def- \\
ecation, urban poor, water \\
sanitation, and hygiene \\
\hline DOI \\
https://doi.org/10.15294/ \\
kemas.v16i2.23019
\end{tabular}

\begin{abstract}
The aim of this study was to obtain a picture on the implementation of Sanitasi Total Berbasis Masyarakat (STBM) the Indonesian term for Community Led Total Sanitation (CLTS) among the families of fisherman in Eretan Kulon, Indramayu West Java. Participants of this Household Survey were categorized into two, namely households that have under-five children and households that have youth. Father or mother or any adult who live with under-five children or youth were purposively chosen as the participants of this study. In total 307 Households (HH Under five 51.14\%; HH Youth 48.86\%) participated in this study. Five pillars of STBM were used to develop a questionnaire for this $\mathrm{HH}$ Survey. The result revealed that among the five pillars of STBM, the highest mean score was in safe management of drinking water and food (Mean=4.08), followed by washing hands with soap (Mean=3.45), management of solid waste (Mean=2.79), management of liquid water (Mean=2.64), and open defecation (Mean=1.90). The result of this study indicated that not all families have latrines so that they still practice of open defecation. The study also showed that solid and liquid waste management is still not considered important to maintain health and environmental hygiene.
\end{abstract}

\section{Introduction}

World Health Organization and the United Nations Children's Fund (2017) reported that in 2015 there were 2.3 billion people in the world who did not get adequate basic sanitation services, and of these numbers there were 892 million people who still practiced open defecation. WHO/UNICEF also shows that almost all the inadequacies in obtaining basic sanitation services are experienced by vulnerable and poor communities, who generally live in rural or slum areas in the cities. In fact, access to proper sanitation services is very important and fundamental to the life of every human being, and therefore water and sanitation apparently become the component of human right that must be facilitated to fulfill (WHO \& UNICEF, 2017). This means that letting people to could not access proper drinking water and adequate sanitation is denying their right to live (Ribeiro, de Abreu \& Laporta, 2018). This also means that the fulfillment of proper sanitation is used as a key indicator in determining the level of a nation's well-being. The better sanitation services that can be obtained by the people, means the higher the level of well-being and vice versa.

Adequate sanitation and hygiene correlate to human and environmental health. Previous studies reported that poor hygiene and sanitation are related to poor health quality. Lawrence, Yeboah-Antwi, Biemba, et.al. (2016) reported that high rates of adults and infant mortality is influenced by the poor quality of health and environmental hygiene. Contaminated food and drinking water, as 
well as unclean and healthy human behavior contribute to the spread of viruses, bacteria and parasites that cause diarrhea (Mara, Lane, Scott \& Trouba, 2010; Walker, Friberg, Binkin, et.al., 2011; Carlton, Liang, McDowell, et.al., 2012; Adane, Mengistie, Kloos, et.al., 2017). The qualities of water, nutrition, sanitation, and hand washing habits have important roles in supporting children's growth and development such as stunting, anaemia and diarrhoea (Larsen, Griham, Slawsky \& Narine, 2017). The long and repeated diarrhoea experiences will likely influence children's cognitive development (Tofail, Fernald, Das, et.al, 2018).

The experience of inadequate drinking water and poor sanitation that caused to diarrhea, as one diseases that cause mortality especially among under-five years children is especially common in poor and low income community (Walker, et.al., 2011; Carlton, et.al., 2012; Tofail, Fernald, Das, et.al, 2018). Tuyet-Hanh, Lee, Oh, et.al. (2016) stated that increasing access to clean water and sanitation can reduce the spread of disease and improve the quality of public health. Therefore, efforts to improve access to clean water sources and better sanitation facilities, especially for underserved communities should be made.

School can be powerful agent of change for advocating and socializing sanitation and hygiene issue. At school children learn about healthy life and clean behaviour to protect themselves and their families from infectious diseases. However, some studies reported that schools do not provide students with adequate sanitation facilities. Majra and Gur (2010) conducted a study on school environment and sanitation in India and the result indicated that not all school provide healthy and clean sanitation facilities, such as drinking water points, adequate latrine for boys and girls, appropriate disposal for liquid and solid waste. Jasper, Le, and Bartram (2012) reported that students' absenteeism, especially female students who are menstruating, is influenced by the availability of water and sanitation facilities. The study also reported that diarrheal and gastrointestinal diseases among students decreased due to increased access to adequate sanitation facilities in school. Magoji, Dedeke, Jaiyeola, Adeniran, et.al. (2017) assessed the support of Water Sanitation and Hygiene (WASH) program on soil-transmitted helminthiasis (STH). The results of the study showed that WASH program at school give positive impact in preventing children from the STH infections. The prevalence of Hookworm, Ascariasis and Trichuriasis is lower among students of WASH program school.

Community Based Total Sanitation (STBM) is the Indonesian terminology used by the Indonesian Ministry of Health for Community Led Total Sanitation (CLTS). CLTS is an approach to tackle open defecation that trigger to the need of community sanitation (Crocker, Saywell \& Bartram, 2017). Referring to the Ministry of Health Decree No. 852/ Menkes/SK/IX/2008 concerning National Strategy for Community Based Total Sanitation, STBM is referred to an approach to change hygiene and sanitation behaviours through community empowerment with triggering methods. Within the decree it is stated that the total sanitation condition is indicated through five indicators, namely stop open defecation, hand washing with soap, safe management of drinking water and food, safe management of domestic solid waste and safe management of domestic liquid waste.

In implementing STBM a participatory method is carried out by empowering and mobilizing the community to change people's behavior regarding open defecation and the provision of latrines that meet hygiene and health standards. In STBM the most important thing is that all resources come from the community. According to Venkataramanan (2015), the main actors involved in the implementation of STBM in Indonesia are national government, local government, nongovernment organization, local health center, village facilitators, and community leaders. Through this participatory approach, it is expected that the changes that occur regarding hygiene and health in the community will be more sustainable (Pickering, Djebari, Lopez, et.al, 2015). Lüthi, McConville and Kvarnström (2010) stated that the strengths of CLTS are in triggering behavior changes and mobilizing the community. Therefore, the success of CLTS is largely determined by the training given to the important figures in the community, and the 
efforts given to overcome the problems faced by the households so that they can make good latrines (Crocker, Saywell \& Bartram, 2017).

The study of Tofail et.al. (2018) showed that intervention program that combine improved water quality, environmental health, hand washing with soap, and nutritional counseling have a positive effect on children's development. In other words, the intervention program will have a positive effect if done through intensive communication related to sanitation and environmental health, both individually and in groups. Pickering, Djebbari, Lopez, et.al. (2015) reported that clean and healthy behavioral intervention programs aimed at improving the quality of water and increasing access to latrines were significantly correlated with the increases of height and weight of the children, especially among chidren under two years old. Referring to the study of Tofail et.al (2018) and Pickering et.al (2015), it is concluded that intervention program intended for improvements of water quality and environmental sanitation have an important role for the growth of children.

Musoke, Ndejjo, Halage, et al. (2018) conducts intervention programs on water, sanitation and hygiene in poor communities in urban areas by involving universities and community members. From the intervention program implemented, it was shown that the health and wellbeing of the community increased. In addition, sincethe local community fully participated in the intervention program, the community considered that the program is part of their lives, which also means that the continuation of the program will occur.

This research was conducted in Eretan Kulon Village, Indramayu District West Java, a traditional fishing village. Traditional fishermen are people who live on the coast and create kinship and do work utilizing fisheries resources by relying on simple fishing equipment (Amiruddin, 2014; Humaedi, 2017; Juliantono \& Munandar, 2016). Traditional fishermen generally only have small business capital and their activities are oriented towards meeting the needs of everyday life (Amiruddin, 2014; Humaedi, 2017; Juliantono \& Munandar, 2016). In some literature, it is explained that fishermen are a group of poor people. In fact, it can be said that compared to other community groups who are both in the agricultural sector, fishermen (especially traditional laborers and fishermen) can be classified as the poorest social strata (Amiruddin, 2014; Humaedi, 2017; Juliantono \& Munandar, 2016). Although it cannot be concluded that all fishermen are poor. Limited capital and technology, affecting the traditional fishing space, so they are less competitive than modern fishermen who have strong capital and sophisticated technology so that the fishing space is wider. Thus, development and technological progress have resulted in the marginalization of traditional fishermen (Amiruddin, 2014; Humaedi, 2017; Juliantono \& Munandar, 2016).

Based on the above explanation, the research question of this study was how the Community Based Total Sanitation or known as Sanitasi Total Berbasis Masyarakat (STBM) implemented among the fishermen families in Eretan Kulon Village, Indramayu District West Java. How do community village perceive the five pillars of CBTS as important factors that support environmental health and hygiene so that they can improve their quality of health and well-being.

\section{Method}

This study carried out in order to obtain picture of the implementation of five pillars of STBM among fisherman families in the village of Eretan Indramayu District, West Java. This study used a mixed of quantitative and qualitative approach. In quantitative approach this study implemented a Household Survey by using questionnaire, while in the qualitative study series of Focus Group Discussions (FGDs) were carried out.

The participants of this study were adult - father or mother or adult who live in the same house with children or youth. Referring to the Convention on the Rights of the Children, children were defined as any individual a boy or a girl below 18 years old. In total 307 households involved in this study [ $\left(\mathrm{HH}_{\text {Under five }}\right.$ $\left.=157 ; 51.14 \%) ;\left(\mathrm{HH}_{\text {Youth }}=150 ; 48.86 \%\right)\right]$. In term of gender $89.25 \%$ of the total participants were female and of that numbers $80.71 \%$ were mothers.

In relation to the participants' education, the data showed that most of the participants 
were graduated from elementary school [ $(\mathrm{HH}$ Under five $\mathrm{n}=49 ; 31.2 \%)$ and $(\mathrm{HH}$ Youth $\mathrm{n}=53$; $35.3 \%)]$ and never go to school or not graduated from elementary school $\left[\left(\mathrm{HH}{ }_{\text {Under five }} \mathrm{n}=18\right.\right.$; $11.5 \%)$ and $\left(\mathrm{HH}_{\text {Youth }} \mathrm{n}=42 ; 28 \%\right)$ ]. If "never go to school", "do not complete elementary school" and "graduated from elementary school" were put together and categorized as low level of education, then the percentage of low level of education was $\mathrm{HH}$ Under five $45.9 \%$ and $\mathrm{HH}$ Youth $76.6 \%$. Number of participants who graduated from high school and undergraduate program was small ( $\mathrm{HH}_{\text {Under five }} 19.8 \%$ and $\mathrm{HH}_{\text {Youth }} 5.3 \%$ ). Five pillars of STBM namely stop open defecation, washing hands with soap, safe management of drinking water and food, safe management of domestic solid waste, and safe management of domestic liquid waste were used to develop questionnaire on the implementation of STBM. Series of Focus Group Discussions (FGDs) were carried out in order to gain deeper information on the implementation of STBM in the neighborhood of Eretan village. FGDs protocol was developed for guidance. In total there were 6 groups of FGDs, namely group of fathers, mothers, boys, girls, youth organization and health cadres. Ethical approval for this study was approved by the Ethics Committee of Institute for Research and Community Services Atma Jaya Catholic University of Indonesia No. 1497/III/LPPM-PM.10.05/11/2018.

\section{Results and Discussion}

Regarding community's perceptions on the five pillars of STBM, the data showed that pillar 3 (safe management of drinking water and food; Mean 4.08) was perceived as the most important for sanitation and hygiene, followed by pillar 2 (washing hands with soap; Mean 3.45), pillar 4 (safe management of solid waste; Mean 2.79) and pillar 5 (safe management of liquid waste; Mean 2.64). Pillar 1 (stop open defecation) was perceived as the least important of sanitation and hygiene (Mean average 1.90).

Based on the FGDs it was indicated that the community awareness on sanitation and hygiene is low. Instead of their own awareness and responsibility, the community is more entrusting the cleanliness of their environment to the janitor who has been paid to carry out his duties.
"Back again, the level of public awareness is not there yet" (FGD with group of Youth Club/Karang Taruna) "It's just that the problem of environmental hygiene seems like being underestimated. In my environment, there is no awareness about it .. "(FGD with group of youth club)

"Village officials have given efforts to the community about the awareness of maintaining environmental hygiene, but those who take out the garbage and clean the sewers are coolies or paid janitors. So it does not connect between the awareness and behavior of environmental hygiene (FGD with group of fathers)

The first indicator of STBM is every individual in the community have access to basic sanitation facilities to realize the community free from open defecation in any place. The result of this HH Survey indicated that not all households in Eretan Kulon Village, Indramayu District have latrines in their home. Only 64.3\% $(\mathrm{n}=101)$ of the $\mathrm{HH}_{\text {Under five }}$ and $69.3 \%(\mathrm{n}=104)$ of the $\mathrm{HH}_{\text {Youth }}$ who said has latrines or toilets. The households who do not have their own toilets or latrines in their home often use public toilets or go to any places (e.g. the sea side) for bowel movements. The community does not realize yet that by practicing open defecation, there is environmental pollution that affects health such as diarrhea and worms. The experience of prolonged diarrhea and worms can affect to the quantity and quality of food intake which in the future will affect cognitive development, especially in children (Mara, et.al., 2010; Walker, et.al., 2011; Carlton, et.al., 2012; Adane, et.al., 2017; Magoji, et.al., 2017; Tofail, et.al, 2018)

When FGD were conducted with health cadres, one health cadres said that there were times when people chose to defecate on the ground in front of their homes. Also, based on observations when the survey was conducted, there were children who suddenly ran and defecated in the middle of the road that was usually passed by local residents.

\footnotetext{
"Sometimes in the hut, there is no
} 
toilet. In front of the hut there is a soil to bury the feces. Like a cat" (FGD with group of health cadres)

"Children do not want to go to the toilet (public toilet), because it is far away. It is also a habit when they were young (FGD with group of mothers)

"The children defecate while playing with friends, so any places" (FGD with group of mothers).

There are several reasons why households do not have toilets or latrines to defecate, namely: (1) there is no money to build latrines ( $\mathrm{HH}$ Under five 67.9\%; HH Youth 64.4\%), (2) there are already public toilets, so there is no need to build our own latrine $(\mathrm{HH}$ Under five $17.9 \%$; $\mathrm{HH}$ Youth $17.8 \%)$, (3) space is limited in the environment $\left(\mathrm{HH}\right.$ Under five $3.6 \% ; \mathrm{HH}_{\text {Youth }} 11.1 \%$ ), and (4) easy to defecate anywhere and no one disputes ( $\left.\mathrm{HH}_{\text {Under five }} 5.4 \% ; \mathrm{HH}_{\text {Youth }} 2.2 \%\right)$. Data from the survey shows that of households who claim they have latrines (201 families) only $72.14 \%$ have their own septic tanks for feces distribution. Sewage disposal is carried out in ponds $(10.45 \%)$, drainage channels (13.86\%), rivers $(15.84 \%)$, shared septic tanks and others (5.94\%). The result of this study also shows that having a toilet at home to be used by family members is a luxury that is difficult to meet, and not a basic need that must be met as a condition for a decent living (Pickering, et.al., 2015; Musoke, et al., 2018; Tofail et.al., 2018)

The aim of pillar 2 in STBM is that hand washing facilities (water and soap) are available in every households and public services facility in the community (i.e. schools, offices, restaurants, health centers, markets, terminals), so that everyone can wash their hands properly. Data from this household survey indicated 93\% of the participants responded that water is available for hand washing. However, only $86.6 \%$ said that soap is available for hand washing.

In pillar 2 of STBM hand washing with soap behavior is revealed in six conditions, and this survey showed that not all participants wash their hands with soap, in the following conditions: 1) before preparing food (88.92\%), 2) before eating $(97 \%), 3)$ after defecating $(98.05 \%), 4)$ before feeding the baby $(94.14 \%)$, 5) before and after cleaning baby feces $(97.07 \%)$, and 6) after holding livestock or pets (95.44 $\%)$. The result of this study shows that the community in Eretan Village still did not see soap as an important object that must be use to wash hands thoroughly. There is possibility because the soap also has a price so that they see soap as a luxurious object that is difficult to fulfill (Republic of Kenya, UNICEF \& Water and Sanitation Program, 2009)

When asked about the habit of washing hands with soap, children answered they did not always wash their hands with soap after doing activities that could bring worm and germs. Washing hands with soap is only done occasionally. According to mothers, they need to force their children to wash their hands with soap. Therefore, hand washing with soap is only done by children because they are afraid of their mothers rather than their own awareness to keep clean and healthy.

\footnotetext{
"Sometimes yes and sometimes no" (FGD with group of girls)

"I forced my kids to wash their hands

..." (FGD with group of mothers)

"Wash his hands, if only mother is there" (FGD with group of mothers)
}

In Pillar 3, it is expected that each household has implemented safe management of drinking water and food. This survey indicated that not all households kept drinking water (98.05\%) and store food $(95.77 \%)$ in a closed container. Only $85.02 \%$ of the participants said that the water container washed and cleaned at least once a week.

Regarding vegetables processing, prior to cook the vegetables $59.61 \%$ said that they wash and cut them, and $35.50 \%$ said that they cut and wash them. Meanwhile, $4.89 \%$ said that they cut and cook the vegetables without washing them. The data indicated that not all families understand how to process the vegetables.

Pillar 4 deals with solid waste management carried out by the community. This survey indicated that only $78.83 \%$ of the households participated in this survey said that they have trash bin in the house, and those who do not have trash bin said that they just scattered the garbage scattered on the home page. Regarding the methods of solid waste 
processing, the most common treatment is throw the garbage into the river or sea (59.93\%), put the garbage in a plastic bag then throw it in the trash (49.3\%), put the garbage in a plastic bag and burn it (30.62\%). Only few of the participants who said that they sort the trash and sell part of it (15.64\%), or process it and make compost (5.54\%), or sort and reuse some of it $(5.54 \%)$. The data indicated that very few of the households who understand and practice the reused and recycle principles of waste by sorting the dry from the wet garbage (17.92\%).

When asked about the habit of disposing the garbage, children as well as mothers responded that there were those who threw garbage in their place but there were also those who littered.

"To the trash, but there are those
who careless" (FGD with group of
children)
"Throw it under the floor" (FGD with
group of children)
"If there is a trash bin in the house,
then throw in the trash bin. But,
when I was out of the house, just
throw it anywhere (FGD with group
of mothers)

Referring to the above data it can be concluded that community awareness on cleanliness remain low. The schools have taught about the children on the importance of cleanliness, and to sort out the trash. However, the knowledge being provided by teachers does not give positive impact on their behavior, since at home children are not concerned about cleanliness.

Only $37.46 \%$ of the participants of this household survey said that there is water absorption in their home, and the number was in line with as many as $42.67 \%$ of the participants who said that they saw a pool of water in their neighborhood. Drains owned by households are more in the form of open channel, where the condition of the channel cannot flow smoothly or in other words sometimes the channel can flow and sometimes clogged (49.19\%). Only $29.97 \%$ of the participants said that the sewerage in their neighborhood can flow properly.

Referring to the waste liquid management, there were five method of managing the liquid waste: 1) just throw it away in the yard/road until it is flooded (12.70\%) 2) discharged to a closed storage infiltration well $(15.96 \%), 3)$ discharged to an open storage infiltration well $(13.68 \%), 4)$ directly flowed to the drain channel, river and the sea (82.08\%), and 5) some were collected to water the plants $(5.86 \%)$. Based on the observation during the research process, it was seen that the sewer in the village did not flow properly and found mosquito larvae. This is relevant to the results of the FGD which revealed that most of common disease is dengue fever. From this study it was also shown that not many people understand waste management, both solid and liquid waste. The principle of reduce, reuse, and recycle, in managing waste is still not done, even though they are likely to have enough knowledge about it (Setyowati \& Mulasari, 2013; Laor, Suma, Keawdounglek, \& Hongtong, 2018; ). Based on the above data it can be concluded that only very few of the households who understand and practice about the safe management of liquid waste. If the wastewater is directly discharged into the drain channel or sewer or river without being treated first it can cause water pollution.

\section{Conclusion}

This study shows that the implementation of STBM in Eretan Kulon Village Indramayu District West Java is still not going well. Open defecation is still considered irrelevant to the environmental health and cleanliness. It was the habit since childhood to defecate not in a private latrine. The factor that drives open defecation is the absence of latrines at home. The expensive cost of building latrines is the main factor that causes no latrines at home, and as a result people rely on the existence of public toilets which cannot be ascertained by their cleanliness.

Referring to the above explanation, it is important to provide recommendations to the local government to conduct interventions related to sanitation and environmental hygiene. In addition, it is also very important to equip key figures with various knowledge and skills aimed at mobilizing local communities to maintain sanitation and environmental hygiene. Previous reports indicated that partnerships with various stake holder i.e. local-government, private sector, universities, 
non-government organizations, and local community play important role for the success of the implementation of STBM. Besides, the continuation of STBM program in the longterm will depend on the involvement of local community in planning, implementing, as well as monitoring and evaluation of the program.

The research was funded by Pertamina Hulu Energy Offshore North West Java (PHEONWJ). The authors would like to thank PHEONWJ and all participants in this study for their support. Appreciations were also granted for all data collector and team member of this study.

\section{Acknowledgement}

The research was funded by Pertamina Hulu Energy Offshore North West Java (PHEONWJ). The authors would like to thank PHEONWJ and all participants in this study for their support. Appreciations were also granted for all data collector and team member of this study.

\section{References}

Amiruddin, S., 2014. Jaringan Sosial Pemasaran pada Komunitas Nelayan Tradisional Banten. Komunitas: International Journal of Indonesian Society and Culture, 6 (1),pp.106114.

Adane, M., Mengistie, B., Kloos, H., Medhin, G., \& Mulat, W., 2017. Sanitation Facilities, Hygienic Conditions, and Prevalence of Acute Diarrhea Among Under-Five Children in Slums of Addis Ababa, Ethiopia: Baseline Survey of a Longitudinal Study. PLoS ONE, 12(8),pp.1-18.

Carlton,E.J., Liang, S., McDowell, J.Z., Li, H., Luoe, W., \& Remais, J.V., 2012. Regional Disparities in the Burden of Disease Attributable to Unsafe Water and Poor Sanitation in China. World Health Organization. Bulletin of the World Health Organization, 90(8),pp.578-87.

Crocker, J., Saywell, D. \& Bartram, J., 2017. Sustainability of Community-led Total Sanitation Outcomes: Evidence from Ethiopia and Ghana. International Journal of Hygiene and Environmental Health, 220,pp.551-557.

Garna, J.V., Sclar, G.D., Freeman, M.C., Penakalapati, G., Alexander, K.T., Brooks, P., Rehfuess, E.A., Boisson, S., Medlicott, K.O., Thomas, F., \& Clasen, T.F., 2016. The Impact of Sanitation Interventions on Latrine Coverage and
Latrine Use: A Systematic Review and Metaanalysis. International Journal of Hygiene and Environmental Health, 220,pp.329-340.

Humaedi, M.A., 2017. Kemiskinan Nelayan: Studi Kasus Penyebab Eksternal dan Upaya Revitalisasi Tradisi Pengentasannya di Kaliori, Rembang, Jawa Tengah. J Sos Ekon Kelaut dan Perikan, 7(2):193.

Jasper, C., Le, T-T., \& Bartram, J., 2012. Water and Sanitation in Schools: A Systematic Review of the Health and Educational Outcomes. International Journal of Environmental Research and Public Health, 9,pp.2772-2787.

Juliantono, F.J., \& Munandar, A., 2016. Fenomena Kemiskinan Nelayan: Perspektif Teori Strukturasi. J Kaji Polit Dan Masal Pembang, 12(2),pp.1857-1866.

Laor, P., Suma, Y., Keawdounglek, V., \& Hongtong, A., 2018. Knowledge, Attitude, and Practice of Municipal Solid Waste Management Among Highland Residents in Northern Thailand. Journal of Health Research, 32(2),pp.123-131.

Larsen, D.A, Grisham, T., Slawsky, E., \& Narine, L., 2017. An Individual-level Meta-analysis Assessing the Impact of Communitylevel Sanitation Access on Child Stunting, Anemia, and Diarrhea: Evidence from DHS and MICS Surveys. PLoS Neglected Tropical Dissease, 11(6),pp.e0005591.

Lawrence, J.J., Yeboah-Antwi, K., Biemba, G., Ram, P.K., Osbert, N., Sabin, L.L., \& Hamer, D.H., 2016. Beliefs, Behaviors, and Perceptions of Community-led Total Sanitation and Their Relation to Improved Sanitation in rural Zambia. American Journal of Tropical Medicine and Hygiene, 94(3),pp.553-562.

Lüthi, C., McConville, J., \& Kvarnström, E., 2010. Community-based Approaches for Addressing the Urban Sanitation Challenges. International Journal of Urban Sustainable Development, 1(1-2),pp.49-63.

Mara, D., Lane, J., Scott, B., \& Trouba, D., 2010. Sanitation and Health. PLoS Medicine, 7(11),pp.e1000363.

Mogaji, H.O., Dedeke, G.A., Jaiyeola, O.A., Adeniran, A.A., Olabinke, D.B., Oluwole, A.S., Abe, E.M., Adeaga, D.O., Yusuff, Q.A., Yusuff, H.A., \& Ekpo, U.F., 2017. A Preliminary Survey of School-based Water, Sanitation, Hygiene (WASH) Resources and Soil Transmitted Helminthiasis in Eight Public Schools in Odeda LGA, Ogun State, Nigeria. Parasitology Open, 3(e16),pp.1-10.

Musoke, D., Ndejjo, R., Halage, A.A., Kasasa, S., Ssempebwa, J.C., \& Carpenter, D.O., 2018. Drinking Water Supply, Sanitation, and 
Hygiene Promotion Interventions in Two Slum Communities in Central Uganda. Journal of Environmental and Public Health, 2018.

Pickering, A.J., Djebbari, H., Lopez, C., Coulibaly, M., \& Alzua, M.L., 2015. Effect of a Community-led Sanitation Intervention on Child Diarrhoea and Child Growth in Rural Mali: A Cluster-randomised Controlled Trial. Lancet Global Health, 3(11),pp.e70111.

Republic of Kenya, UNICEF \& Water and Sanitation Program., 2009. Are Your Hands Clean Enough? Study Findings on Handwashing with Soap Behaviour in Kenya.

Ribeiro, M.R., de Abreu, L.C., \& Laporta, G.Z., Drinking Water and Rural Schools in the Western Amazon: An Environmental Intervention Study. PeerJ, 6,pp.e4993.

Setyowati, R., \& Mulasari, S.A., 2013. Pengetahuan dan Perilaku Ibu Rumah Tangga Dalam Pengelolaan Sampah Plastic. Kesmas. National Public Health Journal, 7(12),pp.562 566.

Tofail, F., Fernald, L.CH., Das, K.K., Rahman, M., Ahmed, T., Jannat, K.K., Unicomb, L., Arnold, B.F., Ashraf, S., Winch, P.J., Kariger, P., Stewart, C.P., Colford Jr, J.M., \& Luby, S.P., 2018. Effect of Water Quality, Sanitation, Hand Washing, and Nutritional Interventions on Child Development in Rural Bangladesh (WASH Benefits Bangladesh): A Clusterrandomized Controlled Trial. Lancet Child Adolescent Health, 2(4),pp.255-268.

Tuyet-Hanh, T.T., Lee, J-K, Oh, J., Minh, H.V., Lee, C.O., Hoan, L.T., Nam, Y-S., \& Long, T.K., 2016. Household Trends in Access to Improved Water Sources and Sanitation Facilities in Vietnam and Associated Factors: Findings from the Multiple Indicator Cluster Surveys, 2000-2011. Global Health Action, 9,pp.29434.

Venkataramanan, V., 2015. Testing CLTS Approaches for Scalability CLTS Learning Series: Indonesia Country Report. Chapel Hill, NC: The Water Institute Gillings School of Global Public Health The University of North Carolina at Chapel Hill and Plan International USA Inc.

Walker, C.L.F., Friberg, I.K., Binkin, N., Young, M., Walker, N., Fontaine, O., Weissman, E., Gupta, A., \& Black, R.E., 2011. Scaling up Diarrhea Prevention and Treatment Interventions: A Lives Saved Tool Analysis. PLoS Medicine, 8(3),pp.e1000428.

World Health Organization and the United Nations Children's Fund., 2017. Progress on Drinking Water, Sanitation and Hygiene: 2017 Update and SDG Baselines. Geneva: World Health Organization (WHO) and the United Nations Children's Fund (UNICEF). 